\title{
KARAKTERISASI EDIBLE FILM KOMPOSIT DARI GLUKOMANAN UMBI ILES- ILES (Amorphopallus muelleri Blume) DAN MAIZENA
}

\section{CHARACTERIZATION OF COMPOSITE EDIBLE FILM FROM GLUCOMANAN OF ILES- ILES (Amorphopallus muelleri Blume) TUBER AND MAIZENA}

\author{
Siswanti $^{1)}$, R.Baskara Katri Anandito ${ }^{1)}$, Godras Jati Manuhara ${ }^{1)}$ \\ ${ }^{1)}$ Staf Pengajar Jurusan Ilmu dan Teknologi Pangan, Fakultas Pertanian, UNS \\ Email: siswanti_rosis@yahoo.com
}

\begin{abstract}
Uses of glucomanan and maizena flour combination was presumed to produce strong and elastic edible film as well as to have lower permeability of $\mathrm{H}_{2} \mathrm{O}$. The first stage of this study was isolation and characterization of glucomanan from iles-iles tuber. Glucomanan yield obtained was 9,88\%, while moisture content, ash, protein, and crude fat content respectively was 10,84\%,3,77\%, 1,70\% and 0,42\%. The second stage of this study was characterization of glucomanan-maizena composite edible film mechanical and barrier properties. The increased glucoman concentration tends to increase the edible film's thickness, solvability, tensile strength, and elongasi, but it decreases water vapour transmission rate. The lowest water vapour transmission rate occurs at the edible film with $15 \%$ glucoman addition. In coating method, the best result was obtained composite film $15 \%$ of glucoman-maizena, because its having the lowest weight loss was $0.0597 \mathrm{~g} / \mathrm{hour}$ and indifferent colour brightness of apple until third day observation.
\end{abstract}

Keywords: Iles-iles (Amorphopallus muelleri Blume), glucomanan, edible film, maizena.

\begin{abstract}
ABSTRAK
Penggunaan kombinasi glukomanan dan tepung maizena diduga mampu menghasilkan edible film yang kuat namun tetap elastis serta memiliki permeabilitas terhadap $\mathrm{H}_{2} \mathrm{O}$ yang rendah. Tahap pertama penelitian ini adalah isolasi dan karakterisasi glukomanan dari umbi iles-iles. Randemen glukomanan yang dihasilkan sebesar $9,88 \%$, sedangkan kadar air, abu, protein serta lemak kasar berturut-turut sebesar 10,84\%, 3,77\%, 1,70\% serta $0,42 \%$. Tahap kedua penelitian ini adalah karakterisasi sifat penghambatan dan sifat mekanik edible film komposit glukomanan-maizena. Peningkatan konsentrasi glukomanan cenderung meningkatkan ketebalan, kelarutan, kekuatan regang putus, maupun pemanjangan edible film, namun menurunkan laju transmisi uap airnya. Laju transmisi uap air terendah yaitu edible film dengan penambahan glukomanan sebesar $15 \%$. Tahap ketiga yaitu mengetahui kemampuan edible film dalam menghambat susut berat serta pencoklatan buah apel dengan cara coating. Hasil terbaik diperoleh pada film komposit glukomanan-maizena 15\%, karena memiliki susut berat terkecil yaitu $0,0597 \mathrm{~g} / \mathrm{jam}$ dan kecerahan warna buah apel yang masih tidak beda nyata sampai hari ke- 3 pengamatan.
\end{abstract}

Kata Kunci : Iles-iles (Amorphopallus muelleri Blume), glucomanan, edible film, maizena.

\section{PENDAHULUAN}

Beberapa jenis talas-talasan (Araceae) mempunyai potensi yang sangat besar apabila diproses melalui teknologi tepat guna. Salah satu jenis talas-talasan yang mempunyai banyak keunggulan adalah iles-iles. Iles-iles (Amorphophallus muelleri Blume sin. A. blumei (Scott.) Engler sin. A. oncophyllus Prain) termasuk famili Araceae, merupakan jenis tanaman umbi yang mempunyai potensi dan prospek untuk dikembangkan di Indonesia. Selain mudah didapatkan juga mampu menghasilkan karbohidrat yang cukup tinggi berupa glukomanan (Jansen et al.,1996 dalam Sumarwoto, 2004). Glukomanan dapat digunakan selain untuk makanan, juga untuk berbagai macam industri, laboratorium kimia, dan obat-obatan (Lahiya, 1993 dalam Sumarwoto, 2004).

Iles-iles (A. muelleri) memiliki kandungan glukomanan yang tinggi yaitu sebesar 67\% (Aryadi dan Rumawas, 2006). Glukomanan merupakan suatu bahan pengemulsi (emulgator) pada industri makanan, kertas, dan kosmetika, karena bahan ini di dalam cairan akan membentuk gel yang mempunyai viskositas cukup tinggi (Meir, 1967; Ohtsuki, 1968; Tipson, 1975; dalam Chairu dan Sofnie, 2006). Glukomanan mempunyai sifat-sifat antara selulosa dengan galaktomanan, yaitu dapat mengkristal dan dapat membentuk struktur serat-serat halus. Selain itu, glukomanan juga dapat membentuk gel yang bersifat 
elastis. Keadaan ini mengakibatkan glukomanan mempunyai manfaat yang lebih luas daripada selulosa dan galaktomanan, salah satunya yaitu dapat dikembangkan lebih lanjut menjadi edible film.

Edible film merupakan lapisan tipis yang digunakan untuk melapisi makanan (coating), atau diletakkan di antara komponen yang berfungsi sebagai penahan terhadap transfer massa seperti air, oksigen, dan lemak, atau berfungsi sebagai pembawa bahan tambahan pangan. Dalam berbagai kasus edible film dengan sifat mekanik yang baik dapat menggantikan pengemas sintetik (Krochta dan de Mulder Johnston, 1997). Menurut Susilowati (2001), glukomanan memiliki peranan yang sangat penting dalam pembuatan edible film, karena glukomanan dapat membentuk gel yang bersifat elastis. Sedangkan menurut Fennema (1976), salah satu metode pembuatan edible film adalah dengan pembentukan gel dari biopolimer yang dilanjutkan dengan penguapan pelarut.

Pada umumnya, film yang terbuat dari pati mudah sekali rusak (Barus, 2002). Penggunaan glukomanan dari iles-iles yang dikombinasikan dengan tepung maizena untuk membuat edible film diharapkan akan menghasilkan edible film yang kuat namun tetap ulet atau elastis, serta mempunyai sifat penghambat yang bagus terhadap uap air. Maizena merupakan tepung yang diperoleh dari jagung. Zein dalam maizena mempunyai komposisi asam amino penyusun yang sebagian besar berupa asam amino non polar seperti leusin, prolin, dan alanin (Shewry dan Miflin, 1985 dalam Krochta et al., 1994), kandungan inilah yang diharapkan mampu menurunkan laju transmisi uap air edible film yang dihasilkan.

Dengan mempertimbangkan hal-hal diatas, yaitu potensi sumber daya alam Indonesia yang cukup besar dalam menghasilkan umbi iles-iles, potensi glukomanan dari umbi iles-iles dan maizena dari jagung untuk pembuatan edible film, serta manfaat yang diperoleh dari penggunaan edible film, maka penelitian tentang pembuatan edible film dari tepung komposit glukomanan umbi iles-iles (Amorphopallus muelleri Blume) dan tepung maizena perlu dilakukan. Selain itu, dalam penelitian ini, selain sifat fisik (kelarutan dan ketebalan film) dan mekanik (pemanjangan film (elongasi), kekuatan regang putus (tensile strength)), besarnya efektivitas penghambatan edible film dari tepung komposit glukomanan umbi iles-iles (Amorphopallus muelleri Blume) dan tepung maizena terhadap transfer uap air dan susut berat, serta pencoklatan buah apel yang dikemas juga perlu diteliti.

\section{METODE PENELITIAN}

\section{Bahan dan Alat}

Bahan utama dalam penelitian ini adalah iles-iles (Amorphophallus muelleri Blume) dan glukomanan hasil isolasi. Bahan untuk mengekstraksi glukomanan adalah etanol 95\% dan aquades. Bahan untuk analisis proximat adalah: petroleum eter, $\mathrm{H}_{2} \mathrm{SO}_{4}$ pekat, $\mathrm{HCL} 0,02 \mathrm{~N}$, asam borat $4 \%$, dan aquades. Pembuatan edible film menggunakan bahan-bahan antara lain: glukomanan hasil ekstraksi, maizena, aquades, dan gliserol. Bahan yang digunakan untuk karakterisasi dan aplikasi edible film adalah aquades, larutan garam $40 \%$, apel segar, dan silica gel.

Alat yang digunakan antara lain: blender, oven, waterbath, kain saring, beaker glass, ayakan 80 mesh, eksikator, muffle, kompor listrik. plat plastik, hot plate, magnetig stirer, pengaduk, micrometer Mitutoyo (ketelitian 0,001), Lloyd's Universal Testing Instrument $50 \mathrm{~Hz}$ model $1000 \mathrm{~s}$, stoples plastik dan cawan WVTR, dan timbangan analitik.

\section{Tahapan Penelitian}

Penelitian ini terdiri dari lima tahap utama, yaitu: ekstraksi glukomanan mengacu pada metode (Aminah, 1992); karakterisasi glukomanan (analisa kadar air, protein, lemak, abu, dan karbohidrat by different (Anonim, 1997)); pembuatan edible film yang mengacu pada metode yang dikembangkan oleh Manuhara (2003) yang dimodifikasi dengan metode pembuatan gel glukomanan yang disarankan oleh Aminah (1992) (Gambar 1); karakterisasi edible film (ketebalan, kelarutan, elongasi, kekuatan regang putus, laju transmisi uap air (WVTR) 


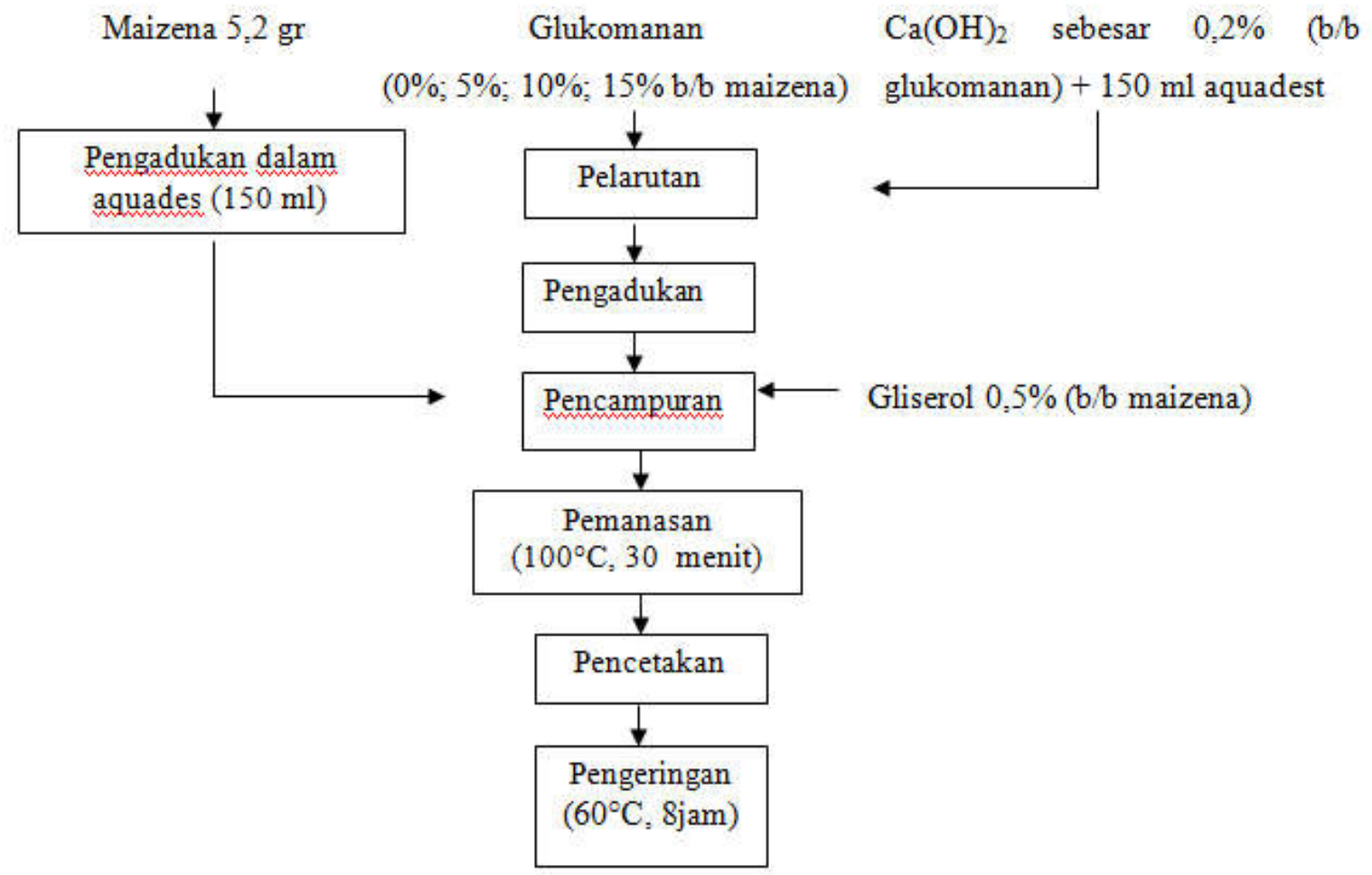

Gambar 1. Diagram alir pembuatan edible film komposit glukomanan-maizena

(Gontard, et. al., 1993)); dan aplikasi edible film (coating pada potongan buah apel, mengacu pada metode yang digunakan $\mathrm{Mg}$ Hugh dan Sanesi (2000) dalam Payung Layuk (2001).

\section{HASIL DAN PEMBAHASAN}

\section{A. Karakterisasi Glukomanan dari Iles- Iles (Amorphopallus muelleri Blume)}

Hasil analisa proximat dan randemen glukomanan tepung iles-iles (Amorphopallus muelleri Blume) disajikan pada Tabel 1.

Tabel 1. Karakteristik Tepung Glukomanan

\begin{tabular}{lll}
\hline & $\begin{array}{l}\text { Kadar wet } \\
\text { basis (\%) }\end{array}$ & $\begin{array}{l}\text { Kadar dry } \\
\text { basis (\%) }\end{array}$ \\
\hline Air & 9,78 & 10,84 \\
Total N & 1,54 & 1,70 \\
Lemak & 0,41 & 0,42 \\
Abu & 3,40 & 3,77 \\
$\begin{array}{l}\text { Karbohidrat } \\
\text { (by different) }\end{array}$ & 84,87 & 94,11 \\
$\begin{array}{l}\text { Serat kasar } \\
\text { Randemen }\end{array}$ & 0,55 & 0,60 \\
\hline
\end{tabular}

\section{B. Karakterisasi Edible Film Komposit Glukomanan - Maizena}

Hasil karakterisasi edible film komposit glukomanan-maizena yang dihasilkan, dapat dilihat pada Tabel 2 .

\section{Pengaruh konsentrasi glukomanan terhadap ketebalan edible film}

Ketebalan merupakan parameter penting yang berpengaruh terhadap penggunaan film dalam pembentukan produk yang akan dikemasnya. Ketebalan film akan mempengaruhi permeabilitas gas. Semakin tebal edible film maka permeabilitas gas akan semakin kecil dan melindungi produk yang dikemas dengan lebih baik. Ketebalan juga dapat mempengaruhi sifat mekanik film yang lain, seperti tensille strength dan elongasi. Namun dalam penggunaannya, ketebalan edible film harus disesuaikan dengan produk yang dikemasnya (Kusumasmarawati, 2007).

Hasil penelitian menunjukkan, peningkatan konsentrasi glukomanan cenderung meningkatkan ketebalan edible film yang dihasilkan. Konsentrasi glukomanan $15 \%$ memberikan nilai ketebalan tertinggi namun tidak berbeda 
Tabel 2. Karakteristik Edible Film Komposit Glukomanan - Maizena

\begin{tabular}{cccccc}
\hline $\begin{array}{c}\text { Konsentrasi } \\
\text { Glukomanan }(\%)\end{array}$ & $\begin{array}{c}\text { Ketebalan } \\
(\mathrm{mm})\end{array}$ & $\begin{array}{c}\text { Kelarutan } \\
(\%)\end{array}$ & $\begin{array}{c}\text { Kekuatan } \\
\text { Regang Putus } \\
(\mathrm{MPa})\end{array}$ & $\begin{array}{c}\text { Elongasi } \\
(\%)\end{array}$ & $\begin{array}{c}\text { Laju Transmisi Uap Air } \\
\left(\mathrm{g} / \mathrm{jam}^{2} \mathbf{m}^{2}\right)\end{array}$ \\
\hline 0 & $0,1613^{\mathrm{a}}$ & $40,57^{\mathrm{a}}$ & $1,25^{\mathrm{a}}$ & $15,56^{\mathrm{a}}$ & $15,60^{\mathrm{c}}$ \\
5 & $0,1604^{\mathrm{a}}$ & $45,70^{\mathrm{b}}$ & $1,41^{\mathrm{a}}$ & $16,48^{\mathrm{a}}$ & $14,54^{\mathrm{b}}$ \\
10 & $0,1807^{\mathrm{b}}$ & $49,80^{\mathrm{b}}$ & $1,42^{\mathrm{a}}$ & $29,07^{\mathrm{b}}$ & $14,72^{\mathrm{bc}}$ \\
15 & $0,1828^{\mathrm{b}}$ & $50,58^{\mathrm{b}}$ & $1,49^{\mathrm{a}}$ & $30,56^{\mathrm{c}}$ & $13,09^{\mathrm{a}}$ \\
\hline
\end{tabular}

nyata dengan penambahan konsentrasi glukomanan $10 \%$.

Semakin meningkat konsentrasi bahan yang digunakan akan menyebabkan peningkatan ketebalan film. Barus (2002) menyebutkan peningkatan ketebalan terjadi disebabkan karena perbedaan konsentrasi bahan pembuat film, sedangkan volume larutan film yang dituangkan masing-masing plat sama. Hal ini mengakibatkan total padatan di dalam film setelah dilakukan pengeringan meningkat dan polimer-polimer yang menyusun matriks film juga semakin banyak.

\section{Pengaruh konsentrasi glukomanan terhadap kelarutan edible film}

Kelarutan film merupakan faktor yang penting dalam menentukan biodegradibilitas film ketika digunakan sebagai pengemas. Ada film yang dikehendaki tingkat kelarutannya tinggi atau sebaliknya tergantung jenis produk yang dikemas (Nurjannah, 2004). Kelarutan tertinggi dari keempat edible film yang dihasilkan adalah pada edible film dengan penambahan glukomanan sebesar 15\%, namun tidak berbeda nyata dengan penambahan glukomanan $10 \%$ dan $5 \%$. Penambahan glukomanan secara nyata mampu meningkatkan kelarutan film. Hal ini terlihat dari edible film kontrol (tanpa penambahan glukomanan) yang memiliki kelarutan terendah, dan berbeda nyata dengan ketiga film komposit glukomanan yang lain. Peningkatan jumlah komponen yang bersifat hidrofilik, yaitu glukomanan dalam edible film, diduga yang menyebabkan peningkatan persentase kelarutan film.

\section{Pengaruh konsentrasi glukomanan terhadap kekuatan regang putus edible film}

Peningkatan

konsentrasi

glukomanan, cenderung meningkatkan kekuatan regang putus (tensile strength) edible film yang dihasilkan. Namun berdasarkan hasil uji statistik, tidak terdapat perbedaan kekuatan regang putus yang signifikan antar keempat jenis edible film. Hal ini menunjukkan bahwa variasi konsentrasi glukomanan yang ditambahkan (5; 10; 15\%) tidak berpengaruh nyata terhadap kekuatan regang putus edible film komposit glukomanan-maizena yang dihasilkan. Manuhara (2003) menyebutkan, biasanya sifat mekanik film tergantung pada kekuatan bahan yang digunakan dalam pembuatan film, untuk membentuk ikatan molekuler dalam jumlah yang banyak dan atau kuat. Menurut Wu \& Bates (1973) dalam Suryaningrum dkk. (2005) edible film dengan kekuatan tarik tinggi akan mampu melindungi produk yang dikemasnya dari ganggunan mekanis dengan baik, sedangkan kekuatan tarik film dipengaruhi oleh formulasi bahan yang digunakan.

\section{Pengaruh konsentrasi glukomanan terhadap elongasi edible film}

Berdasarkan hasil uji statistik, penggunaan konsentrasi glukomanan sebesar $5 \%$ tidak berbeda nyata dengan film kontrol, namun berbeda nyata pada film dengan penambahan glukomanan $10 \%$ dan $15 \%$. Penambahan konsentrasi glukomanan 15\% memberikan elongasi terbesar dibandingkan ketiga edible film yang lain. Nilai elongasi edible film komposit maizena glukomanan berkisar antara 15,56\% - 30,56\%. Apabila dibandingkan dengan edible film yang dibuat dari komposit protein biji kecipir dan tapioka yang memiliki elongasi 1,68\%-3,48\% 
(Poeloengasih, 2001) serta edible film dari ekstrak daun janggelan yang memiliki elongasi $0,14 \%-0,27 \%$ (Murdianto dkk., 2005), edible film komposit maizena glukomanan memiliki nilai elongasi yang jauh lebih besar.

\section{Pengaruh konsentrasi glukomanan terhadap laju transmisi uap air edible film}

Kemampuan edible film dalam menahan migrasi uap air dari buah merupakan sifat yang penting untuk diketahui, karen menurut Gontard et.al. (1993), salah satu fungsi edible film adalah untuk menahan migrasi uap. Krochta et. al. (1994) juga menyebutkan, pada umumnya kehilangan air pada produk buah-buahan dan sayur-sayuran merupakan penyebab utama kerusakan selama penyimpanan. Kehilangan air tersebut dapat menyebabkan buah-buahan dan sayuran mengalami susut berat dan tampak layu atau berkerut sehingga kurang diminati oleh konsumen.

Peningkatan konsentrasi glukomanan cenderung menurunkan laju transmisi uap air edible film. Hal ini diduga karena meningkatnya molekul dalam larutan akan menyebabkan matrik film semakin banyak, sehingga film yang kuat, dengan struktur jaringan film yang semakin kompak dan kokoh, sehingga meningkatnya kekuatan film untuk menahan uap air. Selain itu, penggunaan maizena sebagai bahan pembuat edible film diduga mampu menurunkan laju transmisi uap air dari film yang dihasilkan. Hal ini diindikasikan dari laju transmisi uap air edible film komposit glukomananmaizena yang lebih rendah daripada edible film komposit glukomanan-tapioka yang pernah diteliti Manuhara, dkk (2008). Laju transmisi uap air edible film komposit glukomanan-tapioka berkisar antara 19,43 21,64 g/jam.m ${ }^{2}$.

\section{Aplikasi Edible Film Komposit Glukomanan - Maizena pada Buah Apel}

\section{Pengukuran Susut Berat Buah Apel}

Pada pengukuran susut berat buah apel dengan metode coating, jenis perlakuan yang dibandingkan adalah, potongan apel tanpa coating, coating dengan film maizena tanpa glukomanan, dan film terpilih hasil penelitian yaitu film komposit glukomananmaizena dengan konsentrasi glukomanan $15 \%$. Hasil pengamatan terhadap susut berat potongan buah apel disajikan pada Gambar 2. Dari Gambar 2 dapat diketahui bahwa susut berat terbesar terjadi pada potongan buah apel tanpa coating. Sedangkan susut berat terendah diperoleh pada potongan buah apel yang dicoating dengan film komposit glukomanan - maizena $15 \%$. Penggunaan glukomanan sebagai bahan dalam pembuatan edible film, ternyata mampu menahan susut berat buah apel lebih besar dibandingkan dengan buah apel yang dicoating dengan film maizena saja, maupun apel yang tidak dicoating.

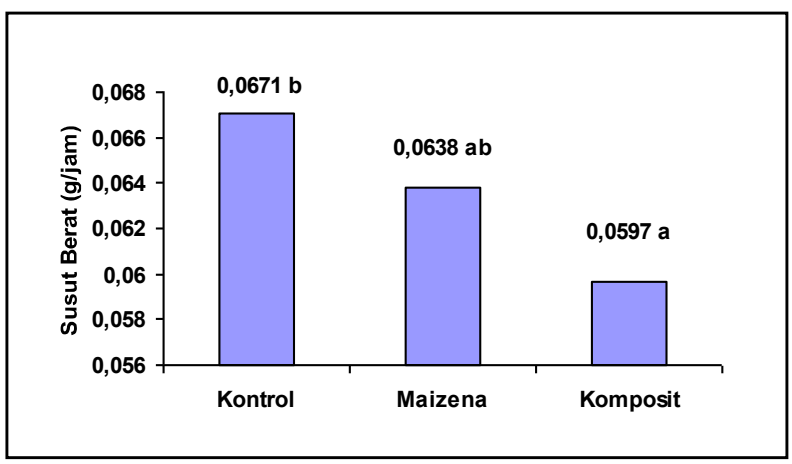

Gambar 2. Susut berat buah apel dengan metode coating

Ket: Kontrol adalah perlakuan potongan buah apel tanpa di coating. Komposisi film maizena : maizena 5,2 gram, gliserol $0,5 \%$ (b/b maizena). Komposisi film komposit : maizena 5,2 gram, gliserol $0,5 \%(\mathrm{~b} / \mathrm{b}$ maizena), glukomanan $15 \%$ (b/b maizena), $\mathrm{Ca}(\mathrm{OH})_{2}$ $(0,2 \% \mathrm{~b} / \mathrm{b}$ glukomanan $)$. Analisa statistik dilakukan dengan Duncan Multiple Range Test pada tingkat signifikansi 0,05 . Angka yang diikuti dengan huruf /notasi yang sama menunjukkan tidak ada beda nyata.

Bertambahnya susut berat buah disebabkan karena terjadinya transpirasi pada buah apel yaitu kehilangan air dari dalam buah melalui pori-pori. Dengan adanya glukomanan sebagai bahan film untuk coating buah apel, peristiwa transpirasi buah apel ini dapat dikurangi. Penggunaan glukomanan dalam jumlah yang lebih besar menyebabkan kemampuan mengikat air yang lebih baik, matrik gel yang dihasilkan lebih banyak, sehingga struktur jaringan film yang dihasilkan semakin kompak dan kokoh. Hal inilah yang kemudian meningkatkan kekuatan film untuk menahan uap air, sehingga dapat 


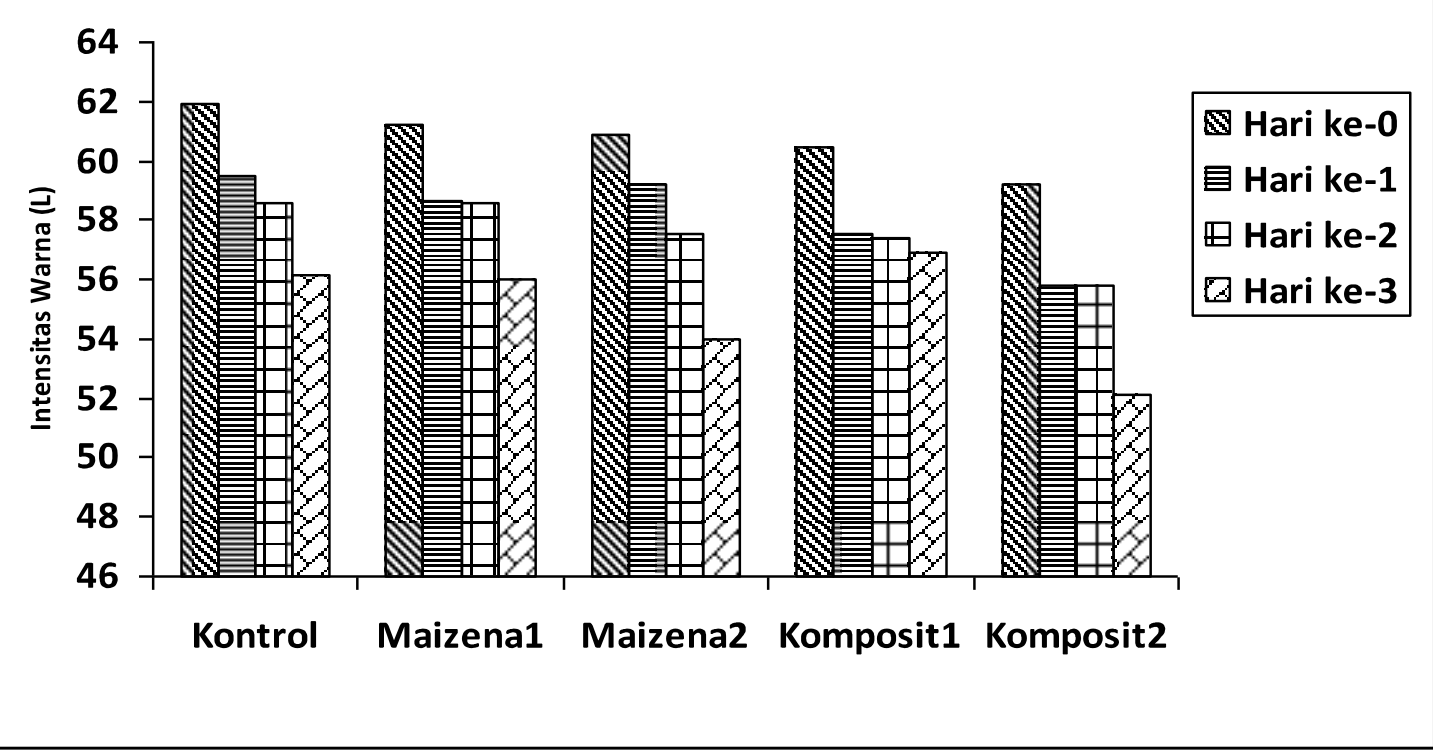

Gambar 3. Grafik Perubahan Warna pada Coating Buah Apel

Kontrol adalah perlakuan potongan buah apel tanpa di coating. Komposisi film maizena : maizena 5,2 gram, gliserol 0,5\% (b/b maizena). Komposisi film komposit : maizena 5,2 gram, gliserol 0,5\% (b/b maizena), glukomanan $15 \%$ (b/b maizena), $\mathrm{Ca}(\mathrm{OH})_{2}(0,2 \% \mathrm{~b} / \mathrm{b}$ glukomanan). Analisa statistik dilakukan dengan Duncan Multiple Range Test pada tingkat signifikansi 0,05. Angka yang diikuti dengan huruf /notasi yang sama menunjukkan tidak ada beda nyata.

menghambat terjadinya susut berat pada buah

\section{Pengamatan Warna Buah Apel}

Daya tarik buah dapat dipengaruhi oleh warna buah itu sendiri. Salah satu cara untuk mencegah terjadinya perubahan warna pada buah apel yang telah dikelupas dan memperpanjang kesegaran apel adalah dengan cara coating. Hasil analisis warna potongan buah apel dengan chromameter ditunjukkan pada Gambar 3.

Pada Gambar 3 terlihat bahwa semakin lama buah apel disimpan, warnanya semakin menurun. Nilai L semakin menurun yang menandakan tingkat kecerahan mulai menurun. Jenis edible film yang digunakan dan lama penyimpanan berpengaruh nyata terhadap warna buah apel. Hasil uji dengan chromameter menunjukkan bahwa pada hari ke-0 potongan buah apel yang mempunyai tingkat kecerahan tertinggi adalah pada potongan buah apel kontrol (tanpa coating), selanjutnya pada film maizena, dan kecerahan terendah adalah pada film komposit glukomanan-maizena. Dari hal ini dapat diketahui bahwa glukomanan sebagai bahan edible film pada aplikasi buah dengan cara coating memberikan tingkat kecerahan yang lebih rendah dibandingkan dengan film dari maizena maupun apel yang tidak di coating. Hal ini disebabkan karena glukomanan sendiri memiki tingkat kecerahan warna yang lebih rendah dibandingkan dengan tepung maizena. Manuhara, dkk. (2008) menyebutkan bahwa tepung iles-iles yang dibuat dari pengeringan umbi yang sebelumnya telah direndam dengan larutan natrium metabisulfit 1000 ppm selama 5 menit, hanya memiliki tingkat kecerahan (L) sebesar 58,29 sehingga glukomanan yang diisolasi dari tepung tersebut diduga juga memiliki tingkat kecerahan yang hampir sama. Glukomanan inilah yang kemudian yang diduga menyebabkan kecerahan warna apel yang dicoating dengan edible film komposit glukomanan-maizena pada hari ke-0 lebih rendah.

Potongan buah apel tanpa coating dan buah apel yang dicoating dengan film maizena, menunjukkan kecerahan warna yang tidak beda nyata sampai hari ke-2 pengamatan, selanjutnya terjadi penurunan kecerahan warna secara nyata. Potongan buah apel yang dicoating dengan film komposit glukomanan-maizena, 
menunjukkan beda nyata mulai hari pertama, dan selanjutnya tidak terjadi perubahan warna yang nyata sampai hari ke-3. Pada tahap awal, perlakuan kontrol, dan film maizena mampu mempertahankan warna potongan buah apel. Namun setelah 3 hari, terjadi penurunan kecerahan warna yang cukup besar. Payung Layuk (2001), yang meneliti warna buah apel pada coating dengan edible film dari komposit pektin daging buah pala dan tapioka, pektin komersial, serta plastik polietilen menunjukkan hasil bahwa, sampai hari ketiga tidak memberikan penurunan kecerahan warna buah apel yang nyata baik pada film pektin isolat maupun komersial. Hal ini diduga karena adanya proses pencelupan potongan buah apel pada campuran larutan asam askorbat dan asam sitrat sebelum tahap coating, sehingga pencoklatan dapat dikurangi pada bagian awal dan seiring dengan lama penyimpanan, efek asam askorbat akan berkurang sehingga pencoklatan tidak dapat dicegah.

\section{KESIMPULAN}

1. Glukomanan hasil isolasi mengandung kadar air 10,84\%, total N 1,70\%, lemak $0,42 \%$, abu $3,77 \%$, serta randemen 9,88\%.

2. Peningkatan konsentrasi glukomanan cenderung meningkatkan ketebalan, kelarutan, kekuatan regang putus, maupun elongasi edible film, namun menurunkan laju transmisi uap airnya. Laju transmisi uap air terendah dihasilkan pada edible film komposit glukomanan-maizena dengan konsentrasi glukomanan sebesar 15\%, yaitu sebesar 13,087 g/jam.m ${ }^{2}$.

3. Edible film komposit glukomananmaizena konsentrasi 15\% mampu menurunkan susut berat potongan buah apel selama penyimpanan sebesar $0,0885 \mathrm{~g} / \mathrm{jam}$. Pada cara coating, hasil terbaik diperoleh pada film komposit glukomanan-maizena konsentrasi $15 \%$, karena memiliki susut berat terkecil yaitu 0,0654 g/jam dan kecerahan warna buah apel yang masih tidak beda nyata sampai hari ke- 3 pengamatan.

\section{DAFTAR PUSTAKA}

Aminah, S., 1992. Kajian Pembentukan Gel Glukomanan dari Umbi Iles-Iles (Amorphopallus oncophylus Pr.) Hasil Pengendapan Glukomanan Dengan Menggunakan Alkohol. Skripsi. Fakultas Teknologi Pertanian UGM. Yogyakarta

Anonim, 1997. Official Methods of Analysis of the Association of Official Analytical Chemists. Association of Official Chemists, Washington DC.

Aryadi, B. dan Rumawas, F., 2006. Percobaan Stek Daun pada Beberapa Jenis Amorphophallus. Departemen Budidaya Tanaman IPB, Bogor. dalam http://bilygila.tripod.com/id7.html (diunduh Selasa, 26 Februari 2007. Jam 09.10 WIB)

Barus, S.P., 2002. Karakteristik Film Pati Biji Nangka (Artocarpus integra Meur) dengan Penambahan CMC. Skripsi. Biologi. Univ. Atma Jaya. Yogyakarta

Chairu dan Sofnie M Chairu, 2006. Isolasi Glukomanan dari Dua Jenis Araceae: Talas \{Colacasia esculenta (L.)\} dan Iles-Iles (Amorphophallus campanulatus Blumei). J. Berita Biologi. 8 (3) :171-178

Fennema, O.R., 1976. Principles of Food Science. Marcel Dekker, Inc., Basset.

Gontard, N., Guilbert., S., dan Cuq, J.L., 1993. Water and Glyserol as Plasticizer Afect Mechanical and Water Barrier Properties of an Edible Wheat Gluten Film. J. Food Science. 58(1): 206 211.

Jansen, P.C.M., C. Van der Wilk, \& W.L.A. Hetterscheid. Amorphophallus Blume ex Decaisne. In M. Flach and F. Rumawas (Eds), 1996. PROSEA : Plant Resources of South-East Asia No 9. Plant yielding non-seed carbohydrates. Backhuys Publishers, Leiden.p 45-50

Krochta,J.M., Baldwin, E.A., dan NisperosCarriedo M.O., 1994. Edible Coatings and Films to Improve Food Quality. 
Technomis Publishing.Co.Inc. Lancester. Bosel.

Krochta \& De Mulder Johnston, 1997. Edible and Biodegradable Polymers Film: Changes \& Opportunities. Food Technology 51

Kusumasmarawati, A.D., 2007. Pembuatan Pati Garut Butirat dan Aplikasinya dalam Pembuatan Edible Film. Tesis. Program Pascasarjana. UGM. Yogyakarta

Lahiya, A.A., 1993. Budidaya tanaman Ilesiles dan penerapannya untuk sasaran konsumsi serta industri. Seri Himpunan Peninggalan Penulisan Yang Berserakan. (terjemahan dari Scheer, J.V., G.H.W.D. Dekker, and E.R.E. Helewijn. 1937/1938/1940.

Manuhara, G.J., 2003. Ekstraksi Karaginan dari Rumput Laut Eucheuma sp. untuk Pembuatan Edible film. Skripsi. Fakultas Teknologi Pertanian UGM. Yogyakarta

Manuhara, G.J., Bambang, S. A., dan Setyaningrum Ariviani, 2008. Ekstraksi dan Karakterisasi Glukomanan Dari Umbi Iles-Iles (Amorphophallus muelleri Blume) Untuk Pembuatan Biodegradable Film. Laporan Kegiatan Program Penelitian Pemula . Propinsi Jawa Tengah

McHugh T.H and Sanesi E, 2000. Apple Wrops. A Novel Method to Improve the Quality and Extend the Shelf Life of Fresh-Cut Apples. J. Food Sci. 56 (3):480-485

Murdianto,W., D.W Marseno., dan Haryadi, 2005. Sifat Fisik dan Mekanik Edible Film dari Ekstrak Daun Janggelan
(Mesona palustris BI). Jurnal Agrosains 18 (3): 353-362

Nurjannah, W., 2004. Isolasi dan Karakterisasi Alginat dari Rumput Laut Sargassum sp. untuk Pembuatan Biodegradable Film Komposit Alginat Tapioka. Skripsi. Fakultas Teknologi Pertanian UGM. Yogyakarta

Payung Layuk, 2001 Karakterisasi Edible Film Komposit Pektin Daging Buah Pala dan Tapioka. Tesis. Program Pasca Sarjana, UGM. Yogyakarta.

Shewry, P.R. and B.J. Miflin, 1985. Seed Storage Proteins of Economically Important Cereals in Advances in Cereal Science and Technology, Vol 7, Y. Pomeranz, ed. St. Paul, MN : American Association of Cereal Chemists. Inc., pp 1-83.

Sumarwoto, 2004. Pengaruh Pemberian Kapur dan Ukuran Bulnil terhadap Pertumbuhan Iles-Iles (Amorphophallus muelleri Blume) pada Tanah Ber-Al Tinggi. J. Ilmu Pertanian. 11(2): 45-53

Suryaningrum Dwi TH, Jamal Basmal, dan Nurochmawati, 2005. Studi Pembuatan Edible Film dari Karaginan. J. Penelitian Perikanan Indonesia. 11(4): $1-13$

Susilowati, E.D., 2001. Komposisi Kimia Berbagai Tepung Iles-Iles dan Kekukuhan Gel Tepung Iles-Iles Ammorphophallus variabilis dengan Variasi Tambahan $\mathrm{Ca}(\mathrm{OH})_{2}$. Skripsi. Fakultas Teknologi Pertanian UGM. Yogyakarta

Wu. L.C. dan Bates, R.P., 1973. Soy protein lipids film, optimum of film formation. J Food Sci. (37):40-44 